\title{
К ВОПРОСУ О НЕОКОНЧЕННОМ ПРЕСТУПЛЕНИИ В УГОЛОВНОМ ПРАВЕ ДРЕВНЕЙ РУСИ
}

\begin{abstract}
Аннотация: Институт неоконченного преступления в уголовном праве древнерусского государства является одним из наименее изученных и, вместе с тем, достаточно спорным. В дошедиих до нашего времени отечественных законодательных памятниках стадии совершения преступления, как правовые явления и понятия о них, нормативно не оформляются, что было вполне естественно для уровня законодательной техники того периода. Различные фрагменты стадий совершения преступления фиксируются казуально, применительно к конкретным случаям из юридической практики и не всегда четко сформулированы. Мнения исследователей по поводу наличия или отсутствия законодательно закрепленных стадий (в основном покушения) в древнерусском уголовном праве разделились и были достаточно аргументированы. Сторонники существования в древнерусском законе положений о неоконченном преступлении настаивают на буквальном его толковании и фиксируют соответствуюшую терминологическую базу. Противники аргументируют свою точку зрения тем, что институт неоконченного преступления в уголовном праве Древней Руси не мог существовать в силу неразвитости субъективной стороны состава преступления. Очевидно, что истина находится где-то посередине - древнерусское уголовное законодательство не успело отразить институт неоконченного преступления, фактически сущуествующий в юридической практике. Во многом этот вывод автора обусловлен сравнительным исследованием некоторых схожих норм законодательства иных славянских государств и стран Западной Европы соответствующей элохи.
\end{abstract}

Ключевые слова: Юриспруденция, приготовление, покушение, злоумышление, обида, намерение, искус, право, суд, древнерусское

ерьезные споры среди исследователей вызывает вопрос о том, существовало ли в древнерусском уголовном праве понятие о стадиях совершения преступления. Мог ли состав неоконченного преступления являться основанием наказуемости. И здесь хотелось бы высказать некоторые предварительные замечания.

Древнерусское уголовное законодательство было уже знакомо с формальными конструкциями составов, во всяком случае, во времена пространных списков Русской Правды. Речь в этих статьях идет о причинении организационно-политического вреда таким объектам, как судебно-публичная власть и княжеское администрирование. Это вновь возникающие объекты охраны. Тем не менее, древнерусскому человеку уже не в новинку понятие о вреде, не получающим обязательного внешнего (объективного) выражения. То есть, иными словами, в уголовном законодательстве древнерусского государства вполне могли появиться некоторые положения, в которых речь могла идти о составе неоконченного преступления.

По всей видимости, древнерусской правоприменительной практике и законодательству (в частности, церковно-уголовному) были знакомы не только покушение на преступление, но и приготовление, а также стадия формирования и обнаружения преступного умысла. Следует, очевидно, согласиться с точкой зрения М. Ф. Владимирского-Буданова о том, что древнерусское уголовное законодательство не предусматривало лишь отказа от доведения преступления до конца. На языке юристов ХІХ в. этот институт получил название «покушения, остановленного по воле преступника». Наказуемость же за отказ от доведения преступления до конца отсутствовала потому, что он обычно остается никому не известным ${ }^{1}$.

Нормативное предписание, в котором можно без труда усмотреть практически все стадии, правда, ограниченные по кругу совершаемых деяний и категорий лиц, содержится в статье пятьдесят третьей Устава князя Ярослава о церковных судах Пространной редакции. Речь в статье идет о юридических основаниях для развода мужа и жены, если со стороны последней будут совершены определенные деяния. Так, в частности, одной из таких «вин» жены становилось ее несообщение мужу о ставшем ей известном факте злых речей или даже злоумышлении

\footnotetext{
${ }^{1}$ Владимирский-Буданов М. Ф. Обзор истории русского права. Ростов-н/Д, 1995. С. 315.
} 
DOI: $10.7256 / 1811-9018.2013 .3 .7528$

При цитировании этой статьи сноска на dоі обязательна

\section{Право и политика 7 (163) • 2013}

в отношении царя или князя ${ }^{2}$. Это косвенное упоминание о чьем-то злом умысле, безусловно, свидетельствует о стадии формирования или обнаружения умысла. Другой такой причиной являлось приготовление или покушение на жизнь мужа, осуществляемое как самостоятельно путем отравления («зелием»), так и с помощью иных лиц («инеми людьми») ${ }^{3}$. Еще одной причиной являлось приготовление или покушение на совершение кражи у мужа, как самостоятельно, так и с помощью иных лиц.

Данная норма является рецепиируемой, она переведена и внесена в редакцию Устава из законодательства Юстиниана ${ }^{4}$. Но она, безусловно, имела практическое применение в древнерусской уголовно-правовой практике. Другой вопрос, что санкция статьи Устава князя Ярослава предполагала лишь осуществление развода с такой женой. Но вряд ли можно себе представить, что, будучи разведенной, женщина, обвиняемая и обличенная в таких преступлениях, могла уйти от последующего уголовного преследования, которое, скорее всего, осуществлялось уже судом княжеским.

А вот наличие или отсутствие указанных положений в светском уголовном законодательстве у исследователей вызывало оживленные споры. Практически не вызывает возражений позиция тех ученых, которые усматривают покушение на преступление в статье пятой Договора Руси и Византии 944 г. «Аще ли кто покусится от Руси взяти что от людии цесаръства нашего, иже то створитъ, покажнен будеть вельми...»5. И действительно похоже, что речь в данной статье идет о покушении.

К такому выводу приходит, например, А. А. Зимин, полагающий, что статья пятая говорит о покушении на грабеж, а термин «покуситься» означает осмелиться или дерзнуть совершить чтолибо ${ }^{6}$. Той же позиции придерживался и М. Ф. Владимирский-Буданов, усматривающий в статье постановление о покушении на грабеж7. О начале преступления в данной статье или покушении на него говорит и Д. Мейчик, отмечая, что статья построена

${ }^{2}$ См.: Российское законодательство X-XX веков: тексты и коммент. в 9 т. / Под общ. ред. О. И. Чистякова. М., 1984. Т. 1. Законодательство Древней Руси. С. 192.

${ }^{3}$ Там же. С. 192.

${ }^{4}$ Там же. С. 207.

${ }^{5}$ См.: Памятники русского права: в 8 вып. / Под ред. С. В. Юшкова. М., 1952. Вып. 1: Памятники права Киевского государства. X-XII вв. С. 32.

${ }^{6}$ Там же. С. 45.

${ }^{7}$ См.: Хрестоматия по истории русского права. Вып. 1: Сост. М. Владимирский-Буданов. Киев, 1876. С. 14. своеобразно: в ней сначала говорится о покушении на преступление, а потом об окончании его ${ }^{8}$. Д. Мейчик, также как и несколько ранее И. Ф. Г. Эверс, отмечают отдельную наказуемость покушения, полагая, что этот факт немаловажен в удостоверении юридической самостоятельности данной стадии преступления 9.

С. Л. Никольский очень удачно подмечает специфику потерпевших в данной статье. Это не просто греки, а приближенные к императору чиновники ${ }^{10}$. Именно поэтому, на наш взгляд, в данной статье речь и идет о покушении, которому византийский законодатель, таким образом, придает повышенную общественную опасность.

Характер же наказания за покушение по статье пятой договора 944 г. является достаточно неопределенным. Объем карательного воздействия выражается во фразе «покажнен будеть вельми», что также различно толкуется учеными. Например, Д. Мейчик видит в этой фразе самоуправство, дозволяющее применять хозяину вещи, на которую покушаются, любые средства и методы для отражения нападения. Потерпевший мог нанести покушавшемуся побои, раны, применить любое другое насилие, однако, он не мог убить нападающего. Это было вызвано, по мнению ученого, тем, что в отличие от труса-вора, которого можно было убить, грабитель вызывал гораздо больше уважения в силу открытости своего нападения ${ }^{11}$.

Напротив, А. Станиславский, отмечающий, что наказание за покушение отличается от наказания оконченного преступления, говорит, что оно уже не созвучно с произволом частного лица, потерпевшего обиду, а является постановлением правительства ${ }^{12}$.

И. Д. Беляев полагает, что такая «неточность»в наказании возникла из-за частных различий видов наказаний у греков и русских. В Греции, согласно данным

${ }^{8}$ Мейчик Д. Система преступлений и наказаний по Договорам Олега и Игоря и Правде Ярослава // Юрид. вестн. 1875. Февраль - март. С. 39.

${ }^{9}$ Мейчик Д. Указ. соч. С. 41; Эверс И. Ф. Г. Древнейшее русское право в историческом его раскрытии. СПб., 1835. С. 195 - 196.

${ }^{10}$ Никольский С. Л. «Мужи цесарства нашего» в свете статьи 12 русско-византийского договора 944 года // Восточная Европа в древности и средневековье: Х Чтения к 80-летию членакорреспондента АН СССР Владимира Терентьевича Пашуто. Москва, 15-17 апреля 1998 г. / Отв. ред. Е. А. Мельникова. М., 1998. C. $84-85$.

${ }^{11}$ Мейчик Д. Система преступлений и наказаний по Договорам Олега и Игоря и Правде Ярослава. С. $41-43$.

12 Станиславский А. Исследование начал имущественных отношений в древнейших памятниках русского законодательства. Казань, 1855. С. $14-15$. 
ученого, в этот период пытки и казни различного вида были в «большом ходу и уважении» ${ }^{13}$.

Чуть менее единодушны исследователи в оценке подобной же статьи в предыдущем договоре Руси и Византии 911 г. В статье седьмой говорится: «О сем. Аще ли кто или Русин Хрестьянину или хрестьян Русину мученьа образом искус творити и насилье яви возметъ что либо дружне...» ${ }^{14}$. Основным спорным моментом явилась фраза «искус творити». Толкования этой фразы действительно очень различны и далеко не все исследователи полагают, что эта фраза юридически созвучна термину «покусится» статьи пятой Договора 944 г.

Так, например, согласно точке зрения Д. Мейчика, как обыск и пытку трактует данную фразу И. Д. Беляев, чья мысль, как мы уже успели заметить, действительно близка к этому. А. Станиславский также уверен, что термин «искус» следует понимать в значении пытания или допрашивания ${ }^{15}$.

А вот И. И. Срезневский, наоборот, считает: «Трудно себе представить, чтобы под словом искус скрывалась мысль о пытке, выпытывании; дело идет о преступлении в роде воровства, соединенного с насилием, о грабеже или разбое (в нынешнем смысле этого слова)». Согласно его точке зрения, эта фраза является буквальным переводом с греческого и означает морских разбойников - пиратов. Просто идея грабежа в Договоре достаточно неловко выражена словом «искус» ${ }^{16}$. Как покушение на преступление понимает данный термин Д. Мейчик ${ }^{17}$.

Не видит ничего иного, кроме причинения страданий и сотворения насилия при завладении чужим имуществом, в данной статье А. А. Зимин ${ }^{18}$. Мы также полагаем, что усмотреть в данной статье контуры покушения еще достаточно сложно, в отличие от статьи пятой последующего договора. Возможно, что покушение появляется только лишь в статье пятой договора 944 г., о чем свидетельствует отдельная наказуемость покушения. А может быть в пятой статье осуществлен более удачный перевод, нежели тот, который был в статье седьмой Договора 911 г.

${ }^{13}$ Беляев И. Д. Лекции по истории русского законодательства. Второе издание. М., 1888. С. 62.

${ }^{14}$ См.: Памятники русского права. Вып. 1. С. 8.

${ }^{15}$ Станиславский $A$. Исследование начал имущественных отношений в древнейших памятниках русского законодательства. С. 9.

${ }^{16}$ Срезневский И. И. Материалы для словаря древнерусского языка по письменным памятникам. Т. 1. СПб., 1893. С. 1123.

${ }_{17}$ Мейчик Д. Система преступлений и наказаний по Договорам Олега и Игоря и Правде Ярослава. С. 40.

${ }^{18}$ См.: Памятники русского права. Вып. 1. С. 19.
Еще меньше согласия по поводу покушения мы находим, анализируя статью тридцатую Пространной редакции Русской Правды: «Аже ударить мечемъ, а не утнетъ насмерть, то 3 гривны, а самому гривну за рану же лечебное; потнеть ли насмерть, а вира» ${ }^{19}$.

Так, например, очень устойчивую позицию по вопросу существования во времена Русской Правды покушения, занял М. Ф. Владимирский-Буданов 20. Ученый полагает, что Русская Правда знает и наказывает действие, начатое, но не достигшее цели, не только посягающее на личность, но и на собственность. «Что касается покушения при преступлениях имущественных, то думают, что оно вообще ненаказуемо по древним законодательствам, в том числе и по Русской Правде; но это лишь недоразумение: вор, схваченный на месте преступления; т. е. не успевший совершить кражи, мог быть убит или схвачен и представлен на княжий двор для суда и наказания, несомненно, равного наказанию за оконченную кражу, ибо здесь разумеется покушение, неоконченное по воле деятеля» ${ }^{21}$. Считает, что отличает от оконченного преступления покушение Русская Правда, А. Попов. По мнению исследователя, покушение это та же обида, хотя и меньшая, а поэтому и наказывается она менее строго 22. Употребляет термин «покушение» применительно к данной статье и Н. А. Неклюдов ${ }^{23}$.

Не менее убедительными являются позиции и противников существования покушения в древнерусском праве эпохи Русской Правды. Согласно точке зрения А. Богдановского, покушения и не могло быть до тех пор, пока преступление рассматривалось преимущественно со стороны лишь фактического (внешне выраженного) причинения вреда ${ }^{24}$. Фактически о том же говорит и М. М. Ковалевский: «Чего Русская Правда еще не знает, так это наказуемости покушения, а потому самому и подстрекательства. О последнем не упоминается ни в одной из ее статей; что же касается

\footnotetext{
${ }^{19}$ См.: Памятники русского права. Вып. 1. С. 111.

${ }^{20}$ Исследователь также усматривает покушение, которое «наказывается в три раза слабее оконченного действия», и в статье двадцать четвертой Пространной редакции Русской Правды, которая гласит: «Аже ли вынезъ мечь, а не утнетъ, то гривна кун» (См.: Правда Русская. Т. 2. / Под ред. Б. Д. Грекова. М.-Л., 1947. С. 341).

${ }^{21}$ Владимирский-Буданов М. Ф. Обзор истории русского права. C. 315 .

22 Попов A. Русская Правда в отношении к уголовному праву. М., 1841. C. $70,87$.

${ }^{23}$ См.: Бернер $A$. Ф. Учебник уголовного права: Часть общая. Части общая и особенная: С примечаниями, приложениями и дополнениями по истории русского права и законодательству положительному. Т. 1. СПб., 1865. С. $169-170$.

${ }^{24}$ Богдановский А. Развитие понятий о преступлении и наказании в русском праве до Петра Великого. М., 1857. С. 125.
} 
DOI: 10.7256/1811-9018.2013.3.7528

При цитировании этой статьи сноска на dоі обязательна

\section{Право и политика 7 (163) • 2013}

до первого, то относимая к нему нередко $20^{25}$ статья Карамзинского списка говорит о чем-то совершенно другом. Обнажение меча, не сопровождаемое нанесением удара, карается не потому, что в нем следует видеть покушение на убийство, а потому, что в заключающейся в нем угрозе законодательство наше наравне с германским усматривает оскорбление чужой чести» ${ }^{26}$. В. И. Сергеевич также считает, что приведенную в качестве примера статью Русской Правды, нужно рассматривать не как покушение на «неизвестное» преступление, а как совершенно самостоятельную обиду, состоящую в угрозе 27 . Считает чуждым древнерусскому праву понятие покушения и его наказуемости, С. Д. Гальперин ${ }^{28}$.

Не очень определенную (промежуточную) позицию по поводу существования покушения в древнерусском уголовном праве занимает Г. Г. Евангулов, который хоть и говорит, что понятия покушения Русская Правда еще не знала, но тут же утверждает, что отдельные случаи покушения признавались самостоятельными преступлениями и сливались с ними ${ }^{29}$. Несколько более понятно объясняет подобное слияние покушения и оконченного преступления в древних памятниках, А. В. Лонгинов. Ученый пишет: «И в краже, и в грабеже, договоры русских с греками не делают существенного различия между покушением на осуществление злого намерения, переходящим в действие, и совершением задуманного преступления, но сливают их при назначении наказания, по приемам римского и древнегерманского прав» ${ }^{30}$.

Подводя предварительный итог столь непростой дискуссии, хотелось бы отметить, что в современном уголовном праве России стадии совершения преступления определяются, прежде всего, как этапы умышленной преступной деятельности лица, различающиеся между собой и по объективным признакам, и по степени реализации умысла виновного лица. В уголовном праве Древней Руси субъективная сторона преступного

\footnotetext{
${ }^{25}$ Карамзинская группа отличается от иных, поэтому номера статей не совпадают.

${ }^{26}$ Ковалевский М. М. Современный обычай и древний закон. Т. 2. M., 1886. С. 87.

${ }^{27}$ Сергеевич В. И. Лекции и исследования по древней истории русского права. М., 2004. С. 269.

${ }^{28}$ Гальперин С. Д. Очерки первобытного права. СПб., 1893. С. 133.

29 Евангулов Г. Г. Юридическая природа покушения // Вестник права. Журнал юридического общества Императорского С.-Петербургского университета. 1902. № $4-5$ (апрель-май). С. 63.

30 Лонгинов A. B. Мирные договоры русских с греками, заключенные в Х веке. Историко-юридическое исследование. Одесса, 1904. C. 137.
}

деяния была менее всего воспринимаемой. Возможно, именно поэтому покушение либо совсем не отражается в уголовном законе, либо, если и получает свое отражение, то юридически значимым не становится еще достаточно долгое время. Законодательное же отражение покушения, особенно в Договорах Руси и Византии и церковно-уголовном законодательстве, во многом является заслугой византийской правовой системы. Примерно о том же говорит Н. Власьев, полагающий, что нельзя ждать от Русской Правды признания понятия покушения, которое «обусловливается ясным и определенным установлением понятия умысла» ${ }^{31}$. «В покушении, которое есть только частичное осуществление намерения, - утверждает С. Будзинский, - воля, т. е. элемент внутренний, субъективный, берет перевес над деянием или элементом внешним» ${ }^{32}$.

Необходимо отметить, что и среди современных исследователей института неоконченного преступления существуют достаточно устойчивые воззрения на несовместимость неразвитости субъективной стороны и стадий совершения преступления в древнерусском уголовном праве. «На наш взгляд, - пишут Г. В. Назаренко и А. И. Ситникова, - вывод о том, что Русская Правда различала покушение на преступление и оконченное преступление, не обоснован, поскольку представление о стадиях преступления, их формах и видах появилось значительно позднее. Русской Правде как источнику обычного права, построенному по казуальному принципу, институт неоконченного преступления был неизвестен хотя бы потому, что во внимание не принималась субъективная сторона деяния, а значит, и этапы ее реализации в действиях обидчика» ${ }^{33}$.

Мы полагаем, что необходимо обратить внимание еще на одну, на наш взгляд, немаловажную особенность. Институты не только покушения, но и приготовления к совершению преступления уже были достаточно знакомы очень многим варварским правдам Западной Европы, стадиально более ранним, чем дошедшие до нас древнерусские законы.

Так, например, в статье двадцать четвертой «О делах, которые относятся к герцогу» Аламаннской Правды VII в. говорится, на наш взгляд, именно о приготовлении. Об этом свидетельствует характер первой фразы статьи: «Если какой-либо человек намеревается

\footnotetext{
${ }^{31}$ Власьев Н. О вменении по началам теории и древнего русского права. М., 1860. С. 187.

${ }^{32}$ Будзинский С. Начала уголовного права. Варшава, 1870. С. 179.

${ }^{33}$ Назаренко Г. В., Ситникова А. И. Неоконченное преступление и его виды: Монография. М., 2003. С. 10 - 12.
} 
лишить жизни другого и будет уличен...» ${ }^{34}$. Очевидно, что речь идет именно об уличении в намерении, а не о прекращении его преступной деятельности в процессе покушения на убийство. Статья двадцать пятая Аламаннской Правды также достаточно ясно упоминает о приготовлении к совершению грабежа и уничтожения чужого имущества: «Если кто-либо пригласит чужой народ в провинцию для того, чтобы там ограбить или поджечь дом и будет в этом уличен...» ${ }^{35}$.

А, например, Салическая Правда VI - IX вв., по словам С. В. Ведрова, вообще предусматривала целое учение о покушении ${ }^{36}$. Правда сформулировано это учение было не в виде общих положений, а применительно к отдельным видам преступлений. Так, параграф первый семнадцатого титула «О ранах» гласит, что если кто-либо вознамерится лишить жизни другого, но промахнется ударом и будет уличен, то присуждается к уплате шестидесяти трех солидов. Необходимо заметить, что штраф за оконченное убийство свободного человека составлял двести солидов, а за нанесение ранений в голову или тело равнялся порядка тридцати солидов. Таким образом, древний франкский законодатель выделил повышенную общественную опасность покушения ${ }^{37}$. Та же самая сумма штрафа назначалась за промах отравленной стрелой, что также расценивалось как покушение ${ }^{38}$.

Интересным представляется также положение, получившее отражение в титуле девятнадцатом «О порче». В соответствии с ним, если кто-либо дал другому выпить отвар трав с целью умертвить, то присуждается к уплате в двести солидов, как за оконченное убийство, независимо от наступивших последствий. Этим лишь подчеркивается, на наш взгляд, повышенная общественная опасность колдовства ${ }^{39}$. Очевидно, что как покушение рассматривалось и проникновение в чужой сад с целью последующего хищения, предусмотренное двадцать седьмым титулом «О различных кражах». К штрафу в пятнадцать солидов в этом случае лицо присуждалось только за сам факт такого проникновения, без каких-либо иных последствий. Причем данный штраф был равен штрафу за хищение, совершенное вне дома, то есть

\footnotetext{
${ }^{34}$ См.: Данилова Г. М. Аламаннское и баварское общество VIII и начала IX в. Петрозаводск, 1969. С. 164.

35 Там же. С. 165.

${ }^{36}$ Ведров С. В. О денежных пенях по Русской Правде сравнительно с законами салических франков. М., 1877. С. $1-2$.

${ }^{37}$ См.: Хрестоматия памятников феодального государства и права стран Европы / Под ред. акад. В. М. Корецкого. М., 1961. С. 12.

${ }^{38}$ Там же. С. 12.

39 Там же. С. 13.
}

без проникновения. Оконченная же кража с проникновением в жилище каралась сорока пятью солидами ${ }^{40}$.

Необходимо отметить, что повышенный и совершенно отдельный штраф за покушение знали и некоторые славянские законы. Достаточно оригинальную трактовку статьи о необходимой обороне в Польской Правде осуществляет М. М. Винавер. Исследователь полагает, что за сам факт покушения на жизнь другого лица, покушающийся, получивший ранение, которое само по себе оценивалось в шесть гривен, платил еще шесть гривен оборонявшемуся лицу. Если все это суммировать, то получалось, что общий штраф за покушение на убийство составлял двенадцать гривен, что на шесть гривен было больше ранения, и на двадцать восемь гривен было меньше штрафа за оконченное убийство ${ }^{41}$.

А вот еще один закон древнего государства франков, составленный придворным аппаратом короля франков Карла Великого и саксонской знатью для саксов (свободных общинников) в $802-803$ гг., положений о неоконченном преступлении, подобных Салической Правде, уже не содержал. Однако, Саксонская Правда (а именно о ней идет речь) включала в себя одну очень интересную, на наш взгляд, норму, подобную статье двадцать четвертой Пространной редакции Русской Правды, о вынимании меча. Это статья восьмая, в соответствии с которой, если кто-либо ринулся на другого с обнаженным мечом, но был задержан другими, присуждался к уплате двенадцати солидов штрафа ${ }^{42}$. Первое, что бросается в глаза это очень невысокий штраф43. Он, фактически, сопоставим с подобным же штрафом в одну гривну в Русской Правде. Очевидно, что подобная похожесть далеко не случайна. Вероятнее всего и в Саксонской, и в Русской Правдах речь действительно идет о чем-то ином, нежели о покушении. Возможно, это расценивалось как оскорбление чести или угроза причинения вреда, а возможно, что все дело было в субъекте данного посягательства - человеке с мечом, по отношению к которому оба закона проявляли большую лояльность в силу его возможно высокого социального статуса. Во всяком случае, подобный вывод напрашивается, если проанализировать еще один

\footnotetext{
${ }^{40}$ Там же. С. 10,14 .

${ }^{41}$ Винавер М. Исследование памятника польского обычного права XIII века, написанного на немецком языке // Варшавские университетские известия. 1888. № 1. С. $158-160$.

${ }^{42}$ См.: Хрестоматия памятников феодального государства и права стран Европы. С. 28.

43 Штраф в Саксонской Правде, например, за синяк был равен шестидесяти солидам, а за более серьезные повреждения он вообще исчислялся сотнями солидов (См.: Хрестоматия памятников феодального государства и права стран Европы. С. 28 и др.).
} 
DOI: $10.7256 / 1811-9018.2013 .3 .7528$

При цитировании этой статьи сноска на ооі обязательна

\section{Право и политика 7 (163) • 2013}

законодательный акт, имеющий отношение к древнерусскому праву - Третью Новгородскую скру (около 1325 г.), представлявшую собой сборник постановлений или статутов для немецких купцов, торговавших в Новгороде. В параграфе сороковом говорится, что если кто-либо обнажит свой меч или нож таким образом, что хочет им поранить кого-либо, то даже если он не причинил никому при этом вреда, то все-равно подлежит уплате штрафа в полторы марки серебром ${ }^{44}$.

Таким образом, можно сделать вывод о том, что институт неоконченного преступления, скорее всего, древнерусской правоприменительной практике был уже знаком, просто по каким-то причинам он не получил четкого законодательного отражения, что и привело к его столь разнообразному последующему толкованию.

\section{Библиография:}

1. Беляев И. Д. Лекции по истории русского законодательства. Второе издание / И. Д. Беляев. - М.: Тип. А. А. Карцева, 1888. - 584 с.

2. Бернер А. Ф. Учебник уголовного права: Часть общая. Части общая и особенная: С примечаниями, приложениями и дополнениями по истории русского права и законодательству положительному. Т. 1 / Бернер А.Ф.; Прим.: Неклюдов Н. - СПб.: Тип. Н. Тиблена и комп., 1865. - 940 с.

3. Богдановский А. Развитие понятий о преступлении и наказании в русском праве до Петра Великого / А. Богдановский. - М.: В тип. Каткова, 1857. - 145 с.

4. Будзинский С. Начала уголовного права / С. Будзинский. - Варшава: Главный склад в книжных магазинах Кожанчикова в С. Петербурге, Варшаве и Казани, 1870. - XI с., 362 с.

5. Ведров С. В. О денежных пенях по Русской Правде сравнительно с законами салических франков / С. В. Ведров. - М.: В универ. тип., 1877. - Х с., 143 с.

6. Винавер М. Исследование памятника польского обычного права XIII века, написанного на немецком языке // Варшавские университетские известия. - 1888. - № 1. - С. 1 - 254.

7. Владимирский-Буданов М. Ф. Обзор истории русского права / М. Ф. Владимирский-Буданов. Ростов-н/Д: Изд-тво Феникс, 1995. - 640 с.

8. Власьев Н. О вменении по началам теории и древнего русского права / И. Власьев. - М.: В университет. тип., 1860. - 238 с.

${ }^{44}$ См.: Таль П. Третья Новгородская скра (около 1325 г.). Текст и русский перевод. М., 1905. С. 31.
9. Гальперин С. Д. Очерки первобытного права / С. Д. Гальперин. - СПб.: Тип. П. П. Сойкина, 1893. - 299 с.

10. Данилова Г. М. Аламаннское и баварское общество VIII и начала IX в. / Г. М. Данилова. Петрозаводск: Изд-во «Карелия», 1969. - 294 с.

11. Евангулов Г. Г. Юридическая природа покушения // Вестник права. Журнал юридического общества Императорского С.-Петербургского университета. - 1902. - № 4 - 5 (апрель-май). - С. $51-69$.

12. Ковалевский М. М. Современный обычай и древний закон. Т. 2 / М. М. Ковалевский. - М.: Тип. В. Гатцук, 1886. - 410 с.

13. Лонгинов А. В. Мирные договоры русских с греками, заключенные в Х веке. Историко-юридическое исследование / А. В. Лонгинов. - Одесса: Экон. тип., 1904. - 163 с.

14. Мейчик Д. Система преступлений и наказаний по Договорам Олега и Игоря и Правде Ярослава // Юрид. вестн. - 1875. - Февраль - март. - С. 32-80.

15. Назаренко Г. В. Неоконченное преступление и его виды: Монография / Г. В. Назаренко, А. И. Ситникова. - М.: Ось-89, 2003. - 160 с.

16. Никольский С. Л. «Мужи цесарства нашего»в свете статьи 12 русско-византийского договора 944 года // Восточная Европа в древности и средневековье: Х Чтения к 80-летию члена-корреспондента АН СССР Владимира Терентьевича Пашуто. Москва, 15-17 апреля 1998 г. / Отв. ред. Е. А. Мельникова. - М.: Институт российской истории РАН, 1998. С. $82-85$.

17. Памятники русского права: в 8 вып. / под ред. С. В. Юшкова. - М.: Госюриздат, 1952. - Вып. 1: Памятники права Киевского государства. XXII вв. -287 с.

18. Попов А. Русская Правда в отношении к уголовному праву / А. Попов. - М.: В университ. тип., 1841. - 121 c.

19. Правда Русская. Т. 2: Комментарии: Сост. Б. В. Александров, В. Г. Гейман, Г. Е. Кочин и др. / Под ред. Б. Д. Грекова. - М.-Л.: Изд-во Акад. наук СССР, 1947. - 862 c.

20. Российское законодательство $\mathrm{X}-\mathrm{XX}$ веков : тексты и коммент. в 9 т. / Под общ. ред. О. И. Чистякова. - М.: Юрид. лит., 1984. - Т. 1. Законодательство Древней Руси. -430 с.

21. Сергеевич В. И. Лекции и исследования по древней истории русского права / В. И. Сергеевич; под ред. и с предисл. В. А. Томсинова. - М.: Зерцало, 2004. - 488 с.

22. Срезневский И. И. Материалы для словаря древнерусского языка по письменным памятникам. 
Т. 1 / И. Срезневский. - СПб.: Тип. Император. акад. наук, 1893. - IX с., 1420 с., 49 с.

23. Станиславский А. Исследование начал имущественных отношений в древнейших памятниках русского законодательства / А. Станиславский. - Казань: Изд. книгопродавца Ивана Дубровина, 1855. - 66 c.

24. Таль П. Третья Новгородская скра (около 1325 г.). Текст и русский перевод / П. Таль. - М.: Универ. тип., 1905. - 40 с.

25. Хрестоматия памятников феодального государства и права стран Европы / Под ред. акад. В. М. Корецкого. - М.: Гос. изд-во юрид. лит., 1961. - 950 с.

26. Хрестоматия по истории русского права. Вып. 1: Сост. М. Владимирский-Буданов. - Киев: В тип. император. ун-та Св. Владимира, 1876. - 228 с.

27. Эверс И. Ф. Г. Древнейшее русское право в историческом его раскрытии / И. Ф. Г. Эверс. - СПб.: Печатано в Тип. Штаба Отдельного Корпуса Внутренней Стражи, 1835. - 422 с.

\section{References (transliteration):}

1. Belyaev I. D. Lekcii po istorii russkogo zakonodatel'stva. Vtoroe izdanie / I. D. Belyaev. - M.: Tip. A. A. Karceva, 1888. - $584 \mathrm{~s}$.

2. Berner A. F. Uchebnik ugolovnogo prava: Chast' obschaya. Chasti obschaya i osobennaya: S primechaniyami, prilozheniyami i dopolneniyami po istorii russkogo prava i zakonodatel'stvu polozhitel'nomu. T. 1 / Berner A.F.; Prim.: Neklyudov N. - SPb.: Tip. N. Tiblena i komp., 1865. - 940 c.

3. Bogdanovskiy A. Razvitie ponyatiy o prestuplenii i nakazanii v russkom prave do Petra Velikogo / A. Bogdanovskiy. - M.: V tip. Katkova, 1857. - 145 s.

4. Budzinskiy S. Nachala ugolovnogo prava / S. Budzinskiy. - Varshava: Glavnyy sklad v knizhnyh magazinah Kozhanchikova v S. Peterburge, Varshave i Kazani, 1870. - XI s., 362 s.

5. Vedrov S. V. O denezhnyh penyah po Russkoy Pravde sravnitel'no s zakonami salicheskih frankov / S. V. Vedrov. - M.: V univer. tip., 1877. - X s., 143 s.

6. Vinaver M. Issledovanie pamyatnika pol'skogo obychnogo prava XIII veka, napisannogo na nemeckom yazyke // Varshavskie universitetskie izvestiya. - 1888. - № 1. - S. 1 - 254 .

7. Vladimirskiy-Budanov M. F. Obzor istorii russkogo prava / M. F. Vladimirskiy-Budanov. - Rostov-n/D: Izd-tvo Feniks, 1995. - $640 \mathrm{~s}$.

8. Vlas'ev N. O vmenenii po nachalam teorii i drevnego russkogo prava / I. Vlas'ev. - M.: V universitet. tip., 1860. $-238 \mathrm{~s}$.
9. Gal'perin S. D. Ocherki pervobytnogo prava/ S. D. Gal'perin. - SPb.: Tip. P. P. Soykina, 1893. -299 s.

10. Danilova G. M. Alamannskoe i bavarskoe obschestvo VIII i nachala IX v. / G. M. Danilova. - Petrozavodsk: Izd-vo «Kareliya», 1969. - 294 s.

11. Evangulov G. G. Yuridicheskaya priroda pokusheniya // Vestnik prava. Zhurnal yuridicheskogo obschestva Imperatorskogo S.-Peterburgskogo universiteta. 1902. - № 4 - 5 (aprel'-may). - S. 51 - 69.

12. Kovalevskiy M. M. Sovremennyy obychay i drevniy zakon. T. 2 / M. M. Kovalevskiy. - M.: Tip. V. Gatcuk, 1886. - $410 \mathrm{~s}$.

13. Longinov A. V. Mirnye dogovory russkih s grekami, zaklyuchennye $\mathrm{v}$ X veke. Istoriko-yuridicheskoe issledovanie / A. V. Longinov. - Odessa: Ekon. tip., 1904. - 163 s.

14. Meychik D. Sistema prestupleniy i nakazaniy po Dogovoram Olega i Igorya i Pravde Yaroslava // Yurid. vestn. - 1875. - Fevral' - mart. - S. 32-80.

15. Nazarenko G. V. Neokonchennoe prestuplenie i ego vidy: Monografiya / G. V. Nazarenko, A. I. Sitnikova. - M.: Os'-89, 2003. - 160 s.

16. Nikol'skiy S. L. «Muzhi cesarstva nashego» v svete stat'i 12 russko-vizantiyskogo dogovora 944 goda // Vostochnaya Evropa v drevnosti i srednevekov'e: X Chteniya k 80-letiyu chlena-korrespondenta AN SSSR Vladimira Terent'evicha Pashuto. Moskva, 15-17 aprelya 1998 g. / Otv. red. E. A. Mel'nikova. - M.: Institut rossiyskoy istorii RAN, 1998. S. $82-85$.

17. Pamyatniki russkogo prava: v 8 vyp. / pod red. S. V. Yushkova. - M.: Gosyurizdat, 1952. Vyp. 1: Pamyatniki prava Kievskogo gosudarstva. X-XII vv. - 287 s.

18. Popov A. Russkaya Pravda v otnoshenii k ugolovnomu pravu / A. Popov. - M.: V universit. tip., 1841. - $121 \mathrm{s.}$

19. Pravda Russkaya. T. 2: Kommentarii: Sost. B. V. Aleksandrov, V. G. Geyman, G. E. Kochin i dr. / Pod red. B. D. Grekova. - M.-L.: Izd-vo Akad. nauk SSSR, 1947. - 862 s.

20. Rossiyskoe zakonodatel'stvo $X-X X$ vekov : teksty $i$ komment. v 9 t. / Pod obsch. red. O. I. Chistyakova. M.: Yurid. lit., 1984. - T. 1. Zakonodatel'stvo Drevney Rusi. - 430 s.

21. Sergeevich V. I. Lekcii i issledovaniya po drevney istorii russkogo prava / V. I. Sergeevich; pod red. i s predisl. V. A. Tomsinova. - M.: Zercalo, 2004. - 488 s.

22. Sreznevskiy I. I. Materialy dlya slovarya drevnerusskogo yazyka po pis'mennym pamyatnikam. T. 1 / I. Sreznevskiy. - SPb.: Tip. Imperator. akad. nauk, 1893. - IX c., 1420 s., 49 s.

23. Stanislavskiy A. Issledovanie nachal imuschestvennyh otnosheniy v drevneyshih pamyatnikah russkogo 
DOI: $10.7256 / 1811-9018.2013 .3 .7528$

При цитировании этой статьи сноска на dоі обязательна

\section{Право и политика 7 (163) 2013}

zakonodatel'stva / A. Stanislavskiy. - Kazan': Izd. knigoprodavca Ivana Dubrovina, 1855. - 66 s.

24. Tal' P. Tret'ya Novgorodskaya skra (okolo 1325 g.). Tekst i russkiy perevod / P. Tal'. - M.: Univer. tip., 1905. - 40 s.

25. Hrestomatiya pamyatnikov feodal'nogo gosudarstva $i$ prava stran Evropy / Pod red. akad. V. M. Koreckogo. - M.: Gos. izd-vo yurid. lit., 1961. - 950 s.
26. Hrestomatiya po istorii russkogo prava. Vyp. 1: Sost. M. Vladimirskiy-Budanov. - Kiev: V tip. imperator. un-ta Sv. Vladimira, 1876. - 228 s.

27. Evers I. F. G. Drevneyshee russkoe pravo v istoricheskom ego raskrytii / I. F. G. Evers. - SPb.: Pechatano v Tip. Shtaba Otdel'nogo Korpusa Vnutrenney Strazhi, 1835. $-422 \mathrm{~s}$. 